\title{
Third Degree Relative
}

National Cancer Institute

\section{Source}

National Cancer Institute. Third Degree Relative. NCI Thesaurus. Code C100808.

Any individual related biologically or leg ally to another individual and considered two degrees removed from the immediate family as in the case of cousins. 